\title{
DISCREPANCY BETWEEN ACTUAL COST AND INDONESIAN CASE BASED GROUPS TARIF IN PUBLIC AND PRIVATE HOSPITALS IN LOMBOK, WEST NUSA TENGGARA
}

\author{
Baiq Holisatul Ismiana'), Didik Tamtomo'), \\ Endang Sutisna Sulaeman') \\ ${ }^{1)}$ Masters Program in Public Health, Universitas Sebelas Maret \\ 2)Faculty in Medicine, Universitas Sebelas Maret
}

\begin{abstract}
Background: Childbirth and maternity-related expenditure is substantial for health insurance. Health insurance may impact childbirth-related healthcare such as cesarean delivery through benefits coverage, payment structures, and provider networks. Indonesia Case Based Groups (INA-CBGs) is an Indonesian payment system used to pay claims from health facilities (such as hospital). This study aimed to examine discrepancy between actual cost and INA-CBGs tarif in public and private hospitals in Lombok, West Nusa Tenggara.

Subjects and Method: This was an analytic observational study conducted at Mataram and Siti Hajar Hospitals, Mataram, West Nusa Tenggara, in May 2019. A sample of 200 patients was selected by stratified random sampling. The dependent variable was discrepancy between actual cost and INA-CBGs tarif. The independent variables were type of hospital, type of class treatment, type of labor, length of stay, and severity. The data were obtained from medical record and analyzed by a multiple logistic regression.

Results: Discrepancy between actual cost and INA-CBGs tarif in birth delivery increased with type III of class treatment $(b=-390,725 ; 95 \% \mathrm{CI}=-790,082$ to 8,$631 ; \mathrm{p}=$ 0.055), caesaria sectio ( $b=-1,429,648 ; 95 \% \mathrm{CI}=-1,811,275$ to $-1,048,022 ; \mathrm{p}<0.001)$, length of stay $(b=-211,912 ; 95 \% \mathrm{CI}=-427,786$ to 3,$960 ; \mathrm{p}=0.054)$, moderate severity $(b=-114,028 ; 95 \% \mathrm{CI}=-507,057$ to 279,$000 ; \mathrm{p}=0.568)$, and severe disease $(\mathrm{b}=-$ $1,735,612 ; 95 \% \mathrm{CI}=-3,482,347$ to 11,$123 ; \mathrm{p}=0.051)$. It was decreased with private hospital $(\mathrm{b}=281,021 ; 95 \% \mathrm{CI}=-73,054$ to 635,$097 ; \mathrm{p}=0.119)$ and type II of class treatment $(b=8,736 ; 95 \% \mathrm{CI}=-392,068$ to 409,$541 ; \mathrm{p}=0.966)$.

Conclusion: Discrepancy between actual cost and INA-CBGs tarif in birth delivery increases with type III of class treatment, caesaria sectio, length of stay, moderate severity, and severe disease. It was decreases with private hospital and type II of class treatment.
\end{abstract}

Keywords: discrepancy, health care, INA-CBGs, tarif, birth delivery

\section{Correspondence:}

Baiq Holisatul Ismiana. Masters Program in Public Health, Universitas Sebelas Maret. Jl. Ir. Sutami 36A, Surakarta 57126, Central Java. Email: baiqholis26@gmail.com. Mobile: +6287739031046 . 